\title{
PARTY POLITICS IN BRITISH GUIANA
}

\author{
C. Paul Bradley \\ Flint College of the University of Michigan
}

$\mathrm{B}$ Y ITS ELECTORAL victory in 1961 Dr. Cheddi B. Jagan's Marxist People's Progressive party won majority control of the popularly elected Legislative Assembly and formed British Guiana's first cabinet government under internal self-government. It was the third successive election won by the P.P.P. and indisputably established this left-extremist party as the colony's most powerful political force. Leader of the parliamentary Opposition is Linden Forbes Burnham, head of the P.P.P.'s closest rival, the moderate socialist People's National Congress. Jagan and Burnham with their attendant political formations have dominated the era of popular politics since the introduction of universal adult suffrage in 1953 and will be the key political figures in the imminent formative phase of an independent Guiana.

In its first decade the Guianese party system has exhibited these major characteristics: (1) Two large mass parties have dominated, the quarter-million electorate being fairly evenly divided between the People's Progressive party and the People's National Congress. (2) The East Indian-African demographic division has constituted the crucial determinant of party affiliation - the P.P.P. drawing its major support from the rural East Indian workers on the coastal sugar plantations and rice farms, while the urbanized African workers in Georgetown, New Amsterdam, and Mackenzie adhere mostly to the P.N.C. (3) The numerically dominant East Indians ${ }^{1}$ are widely dispersed, giving the P.P.P. a considerable advantage in the number of parliamentary seats it normally controls despite the closeness in popular vote. (4) Radicalism has been dominant in the policy preferences and campaign appeals of the two mass parties, both advancing militant claims for national independence and far-reaching social and economic reforms. (5) Both the P.P.P. and P.N.C. have relied on strong central leadership concentrated in single individuals; but this has been modified by an increasingly rationalized organizational structure and professionalism in campaign planning and tactics. (6) Opposition in the General Elections of 1953, 1957, and 1961 has been ineffectual, due to a shifting formation of markedly conservative electoral combinations deriving support chiefly from the small middle class and typically surviving only a single election. (7) Finally, the once-dominant independent has virtually disappeared from Guianese politics. This is exemplified in the contrast between the seventy-nine non-party legislative candidates in 1953 and the five independents in 1961.

The emergence of the Guianese party system is closely associated with the post-World War II period of political ferment and constitutional reform. Important modifications in the established system of Crown Colony government

\footnotetext{
${ }^{1}$ The size of the three politically significant ethnic groups is: 279,460 East Indians, $190,380 \mathrm{Ne}-$ groes, and 66,180 in the mixed category. There are also small Portuguese, Chinese, and Amerindian minorities.
} 
were introduced under the Waddington Constitution adopted in 1953. The most consequential of these was the replacement of the long-standing property and literacy requirements for voting by universal adult suffrage, which more than tripled the electorate. A bicameral legislature was substituted for the unicameral Legislative Council with its slight elective majority. A majority of the constitutional commission favored a nominated upper chamber as a check on the elective lower chamber, representing a partially illiterate electorate. The nominated State Council was given a suspensive veto power over ordinary legislation for one year.

A quasi-ministerial system was established to provide administrative experience for the elective members of an Executive Council, whose six representatives constituted a majority of that ten-man body. The British Governor became its presiding official with a casting vote. He also retained his veto and preserved powers that assured the ultimate control of the Colonial Office. Normally he would act in accordance with advice of the Executive Council.

The initial beneficiary of the first elections held in 1953 under the new constitution was the People's Progressive party, which had been founded in 1950. lt won control of eighteen out of the twenty-four elective seats in the House of Assembly. Scattered opposition to the P.P.P., representing a politically unified working class, came from four minor parties.

In the immediate postwar period Jagan had emerged as the most articulate spokesman for the largely disfranchised masses. In 1943 he had returned to British Guiana after a seven-year period of study at Howard and Northwestern universities, having acquired a degree in dentistry from the latter institution. His book, Forbidden Freedom, portrays his residence in the United States as a time of political awakening. The classics of Marxist philosophy and the works of Jawaharlal Nehru seemingly made the deepest impression. He married an ardent young American Marxist, Janet Rosenberg, who was destined to play an important political role in her husband's mass movement.

In 1946 the Jagans formed the Political Affairs Committee, precursor to the P.P.P. The P.A.C. was militantly socialist and anti-imperialist. Its monthly Bulletin scathingly derided the British firm of Booker's that dominated the colony's crucially important sugar economy. In 1947 Jagan was elected to the Legislative Council under a restricted electorate and began to perceive the desirability of a full-fledged political party based on Marxist principles.

The P.P.P. was conceived as a working-class party that would transcend the basic cleavage between East Indian and African. By advocating nationalist objectives and a program of drastic social and economic reform, and accentuating class rather than ethnic divisions, the P.P.P. hoped to break the entrenched power of the East Indian Association and the League of Colored Peoples. These were large pressure groups dedicated to advancing the political and economic interests of their respective racial communities. Significantly the original leadership of the P.P.P. included Burnham, Ashton Chase, and Sydney King, all Negroes.

The party's centralized organizational structure reflected the Marxist predilections of the P.P.P. leaders. The dominant party organ was the small Executive Committee of twelve members, deriving its legitimacy from the annual Party 
Congress. In an intermediate and much less important position was the General Council of twenty-two members, on which sat seven of the Executive.

At the annual congresses the delegates' support for a series of policy resolutions, mostly under Executive sponsorship, was mobilized. Delegates to these sessions were chosen by the local Party Groups, organized on a colony-wide basis to give the P.P.P. a firm grass-roots foundation. In this organizational activity Mrs. Jagan proved especially adept, her customary formal party post being General Secretary.

Such a systematic party organization was an important innovation in Guianese politics. P.P.P. histories have subsequently drawn a sharp distinction between P.P.P., with its dues-paying, disciplined membership and its marked issue-orientation, and the personal followings of "spoils-seeking" politicians that had previously dominated local politics. The P.P.P. group structure has influenced all later political party formations in British Guiana.

From the outset the P.P.P. was sharply critical of the Waddington Constitution, charging that it perpetuated the territory's colonial status and protected the vital interests of imperialist investors. In particular the implicit check on popular government by means of a nominated upper chamber under the governor's control was denounced as well as the scope of his reserved powers in defense, tariffs, foreign relations, and constitutional questions. The P.P.P. favored a unicameral, wholly elective legislature, a figurehead position for the governor, and the adoption of cabinet government. Agitation for full independence was to continue unabated.

In the 1953 election the P.P.P. espoused a reformist, partly socialist program. Its major planks were the advocacy of rapid Guianization of the Civil Service and foreign businesses, the adoption of a free health service and workmen's compensation, the secularization of the denominationally controlled educational system, full legalization of trade-union organizations and collective bargaining rights, land settlement schemes, governmental encouragement of new industries, and future nationalization of the sugar industry. The party periodical, Thunder, was an important instrument for popularizing these proposals among the rank-and-file party members.

Immediate friction developed between the newly formed P.P.P Government and the British colonial administration. The major complaints lodged by the British against the Jaganite Government were: (1) its fomentation of strikes among the sugar workers, aggressively organized by the Guiana Industrial Workers' Union headed by the P.P.P. Minister, Dr. Lachhmansingh for the alleged purpose of creating economic chaos; (2) its attempt to gain control of the civil service by abolishing the Public Service Commission, hitherto dominated by British civil servants, and "packing" certain statutory boards with P.P.P. appointees; (3) its alleged intention to organize a "people's police" to replace the Britishcontrolled police force, which the P.P.P. deemed unduly solicitous of management in labor disputes; and (4) its alleged arson plot to set fire to business property and residences of Europeans and of Government officials. 
The P.P.P. held power for four stormy months from the end of May to early October 1953. Pleading a grave threat to "public order and the people's livelihood" the British Government then suspended the Waddington Constitution. Governor Sir Alfred Savage declared a state of emergency, dismissed the P.P.P. ministers from office, and prorogued the legislature. A small detachment of British soldiers was landed from Jamaica. A period of wholly nominated government ensued, lasting for four years. A number of P.P.P leaders were jailed and later confined to certain districts, the publication of Thunder was suspended, and political meetings and demonstrations were banned.

In its White Paper defending the constitutional suspension the British Government stressed the manifold connections between the P.P.P. and international communism, especially the participation of P.P.P. leaders in the World Federation of Trade Unions. ${ }^{2}$ Attention was drawn to the affiliation of the P.P.P. youth organization, the Pioneer Youth League, to the allegedly communist-controlled World Federation of Democratic Youth and World Peace Council. The connection of the local Women's Progressive Organization, organized under Mrs. Jagan's leadership, with the Women's International Democratic Federation was cited, as well as the circulation of "communist peace propaganda" by the P.P.P.-dominated British Guiana Peace Committee. It was clear that in 1953 the Colonial Office believed the basic P.P.P. objective was to establish a communist-style satellite regime in British Guiana. This fear governed its markedly punitive action against the P.P.P.

In 1954 the findings of the Robertson Commission, appointed by the Colonial Office to investigate the suspension of the Waddington Constitution, shaped the colony's immediate political future. In its caustic analysis of P.P.P. leadership the Commission carefully distinguished between its doctrinaire communist and more vaguely socialist wings. ${ }^{3}$ The Jagans and King were included in the former category, while the "ambiguous" Mr. Burnham, London University-trained barrister, was appraised as the leader of the rival socialist faction.

The Commission recommended a period of marking time to avoid a second premature advance toward self-government. In its opinion the P.P.P. remained intransigently radical. So long as it retained its present leadership and policies the British should cling to the safeguard of nominated government. Shortly thereafter there occurred in 1955 the fateful split between the Jaganite and Burnham factions within the P.P.P.

This factional division took the form of a bitter struggle to control the existing P.P.P. machinery, in particular the central party organs. Burnham and his supporters were eventually ousted and, following the 1957 election, separately organized the People's National Congress. Originally the split was not primarily ethnic in character. Sydney King and Ashton Chase were among the Negro leaders who initially remained with the Jagans. The East Indians Lachhmansingh and Jai Narine Singh, the latter a militant Guianese nationalist, were for a while officers in the Burnham organization.

${ }^{2}$ British Guiana Suspension of the Constitution, H.M.S.O., Cmd. 8980, 1953.

${ }^{3}$ Report of the British Guiana Constitutional Commission, H.M.S.O., Cmd. 9274, 1954. 
In the frequently iterated P.P.P. interpretation, Burnham, true to his bourgeois background, engineered the split as an opportunistic response to the insistence of the Robertson Commission on a change in P.P.P. leadership as a prerequisite for a restoration of an elective system. Burnham had anticipated, the P.P.P. alleged, that his political organization would benefit from even a partial return of popular government by sharing the "spoils of office." According to the P.P.P. the fissure had permanently baleful consequences because it revived the racialism which the P.P.P. had originally pledged itself to eradicate.

For his part, Burnham stressed the doctrinal emphases between the two rival groups. In his view the Jaganites emphasized the socialist objectives of the P.P.P. at the expense of its nationalist goals, which to Burnham deserved priority. British Guiana should first become independent before turning to fundamental economic reform. The form of Marxism embraced by Burnham was assuredly more eclectic than Jagan's, less geared to a Moscow model. Beyond these ideological overtones Jagan and Burnham were both extremely ambitious for political preferment and were ill-contained within the same organization. Nor could either wholly transcend his disparate ethnic background.

The ethnic aspect of the factional cleavage was markedly apparent in the 1957 election. Despite public professions of a desired national unity both factions made use of racialist appeals in house-to-house canvassing, the Jaganites to the East Indians, the Burnham faction to the Africans.

The election was conducted under the new Renison Constitution which marked a partial return to an elective system. Both factions attacked its limited popular character, but competed for political dominance. Fourteen of the twentyfour seats in the unicameral Legislative Council were to be chosen by popular vote. The nine seats won by the Jaganites were chiefly in the rural East Indian constituencies. The Burnham faction won three seats in urban Georgetown districts with African majorities. Some middle-class African votes went to the United Democratic party, led by a political moderate, John Carter. The U.D.P. and Lionel Luckhoo's conservative National Labour Front won only single seats. None of the six independents won seats, marking the coming of age of the party system.

The main lines of Guianese politics were thus set in 1957: (1) the assumption of governmental responsibility by the Jaganite P.P.P. and its subsequent preoccupation with the administration of a modest program of economic development; (2) the creation of a unified parliamentary Opposition to the P.P.P. Government, led by Burnham, which offered a searching day-by-day criticism of P.P.P. policies; (3) fluidity by the marginal political groupings, epitomized in the merger in 1959 of the U.D.P. with the P.N.C., both African-based, and the gradual disintegration of the conservative N.L.F.

\section{II}

In their advocacy of policies designed to raise the masses' impoverished living standards the two major parties share a considerable consensus, sometimes blurred by campaign hyperbole. Both assert the necessity of governmental initiative to gain an economic "take-off." Both recognize the historic weaknesses of British Guiana's 
reliance on a single-crop economy in sugar production and support economic diversification in agriculture and industry.

While both the P.P.P. and P.N.C. are pledged to the ultimate attainment of their separate versions of socialism, each accepts the interim necessity of a mixed economy dominated by the private sector for an indefinite period. A mixed economy has been defined by both parties as including an uncertain degree of future experimentation with Government-operated factories as well as enterprises jointly operated by Government and private enterprise. A continued tax-concessions policy to attract new foreign business is upheld by both parties.

In the immediate future the nationalization of the British-owned sugar industry is foresworn by both the P.P.P. and P.N.C., but a more rapid Guianization of its managerial ranks is advocated. In the opening up of the largely undeveloped interior of the country the urgent requirement of large-scale external financial aid is recognized by both parties.

In economic policy the P.P.P. is necessarily identified with the present Government's Development Plan of approximately $\$ 73$ million (U.S.) spread over the four-year period 1960-64. The antecedents for this Plan lie in the pre-Jagan period of nominated government of 1954-57 and in similar administrative mechanisms for planned economic development on a small scale frequently adopted in the British colonial world since World War II.

Under Jagan the chief emphasis of this program has been the gradual expansion and diversification in the agricultural sector mainly by governmentally sponsored land settlement schemes along with a number of drainage and irrigation projects. Thus far the most important effect of this program has been the doubling of rice production over the past four years, chiefly by peasant smallholders. Obviously in its initial phases the P.P.P.'s Development policy has not been doctrinaire Marxist.

As the leading out-party the P.N.C. has mobilized telling criticisms of Government's Development Plan. The major points in the P.N.C. attack have been: (1) the insufficiency of governmental funds allocated for development purposes measured in the continued high rate of unemployment of about 17 per cent of the total working force, which means between 25,000 and 30,000 persons; (2) the lack of coordinated economic planning by a central planning unit; (3) the disproportionate concentration on expanding agricultural production at the expense of developing industry; (4) the political motivation for Government's efforts to expand rice production, which allegedly have primarily benefitted East Indian smallholders, mostly P.P.P. adherents; and (5) the P.P.P. preference for using leasehold forms of tenure in Government's land settlement schemes, ignoring the psychic advantage alleged to inhere in freehold tenure in providing the productive stimulus of individual land-ownership.

A P.N.C. Government would alternatively sponsor an accelerated program of economic development based on Caribbean models of proved effectiveness in Puerto Rico, Jamaica, and Trinidad. In addition to the creation of a central planning unit, this would include the establishment of an Industrial Development Corporation to stimulate foreign investment supported by an Industrial Bank for 
short- and long-term loans to new industry and a Central Bank in the Jamaican pattern to control local and foreign currencies.

The P.N.C. conceives a two-stage program of industrialization, beginning with light industry, mostly in agricultural processing, and later extending to heavy industry based on the presently undeveloped hydroelectric power in the interior. Presumably a P.N.C. Government would also pursue an intensified public works program to reduce urban unemployment and allocate increased amounts of Government funds for low-income urban housing projects, both policies with an obviously strong appeal to the urbanized P.N.C. electorate.

Other rather slight differences mark the P.N.C. approach to economic development from that of the P.P.P. Polemically the P.N.C. insists that the Guianese should rely primarily on their own efforts to improve their economic status, implying that the P.P.P. too assiduously courts outside assistance. The P.N.C. favors a proportionately higher Governmental appropriation than those presently allocated to education, particularly for the vocational training of skilled Guianese workers to replace foreign personnel in economic enterprises. At the same time the P.N.C. acknowledges the short-term necessity of using non-Guianese personnel.

In defending present Development policy P.P.P. spokesmen argue that establishing a sound agricultural base must necessarily precede any large-scale industrialization effort. Government investment in land settlement schemes has in fact stimulated employment in service, transport, and commercial occupations. Government expenditures in the agricultural sector have so increased food production that British Guiana boasts a more stable cost of living than any comparable West Indian territory. Among the numerous advantages attributed by the P.P.P. to leasehold forms of tenure is that land speculators are prevented from gaining control of the holdings of peasant farmers who fall into debt. Under leasehold, Government is also enabled to enforce sound agricultural practices proposed by its agricultural experts.

With the advent of independence the P.P.P. argues that the rate of Development spending can be expanded by the concomitant wider availability of foreign loan sources. After the new P.P.P. Government took office in 1961 Jagan added the portfolio of Development and Planning to his new Premiership and took initial steps to establish a central planning unit and a Central Bank. For both these projects Ghanian and Indian advisory assistance is being solicited.

The crucial necessity of large-scale foreign economic assistance for the ultimate success of Development policy is closely linked to the foreign policy declarations of neutralism made by both the P.P.P. and P.N.C. Neither will accept the attachment of political conditions to future foreign loans. Neutralism carries the obvious advantage that negotiations for economic assistance need not be confined to either the Western or Eastern bloc. Assistance from international agencies would arouse the least compunction.

Particularly in the case of the incumbent P.P.P. Government the full implications of present neutralist professions must await the granting of full independence. In the P.P.P. leadership there has long existed an uncritical admiration for the Soviet Union and all its works, resting on the firm conviction that the So- 
viet bloc rides the dialectical wave of the future. Closer to home the advent of the quasi-communist regime in Cuba has evoked widespread interest and approval among P.P.P. leaders. In the 1961 campaign the P.P.P. made political capital of its Government's expanding trade relations with the Castro Government. Cuba now purchases under a five-year agreement the entire surplus rice production of British Guiana and has offered a substantial low-interest loan to develop the Guianese timber industry.

At the same time Jagan has indicated his Government will probably adhere to the Latin American Alliance for Progress under American auspices and already in Washington has actively sought substantial financial assistance for economic development. The final outcome of this complex of negotiations will strongly influence a possible future modification in the customary antipathy with which the P.P.P. has viewed Western-bloc foreign policies, as evidenced in the street demonstrations it organized in 1961 against the U.S.-sponsored Cuban invasion.

Yet another strand in the external preferences of the P.P.P. is a considerable inclination to follow the model of development policies in Nehru's India, buttressed by a degree of emotional pride in Indian achievements common to the predominantly East Indian leadership of the P.P.P. Closely related to this attitude is the keen interest the Jaganites evidence in both the domestic and foreign policies of the neutralist bloc of Asian and African nations, a recent token manifestation of which was Jagan's attendance at Tanganyika's independence ceremonies. The most probable future direction in foreign policy of an independent P.P.P. Government is nominal adherence to the British Commonwealth coupled with an active participation in the pro-Soviet segment of the neutral bloc. Until the question of economic aid is resolved, a certain restraint and caution is likely to mark its relations with the United States.

The official neutralist statements of the P.N.C. cloak a different set of sympathies. Until the announcement of the Jamaican referendum on continued adherence to the West Indies Federation the P.N.C. evidenced a positive attitude toward the evolution of that grouping, whose Negro leadership had an understandably strong appeal. Now that Jamaica's withdrawal jeopardizes the future of the Federation the P.N.C. follows a policy of watchful waiting. This caution is reinforced by the large amount of known anti-Federation sentiment among the predominantly East Indian population in British Guiana. Due partly to the negative reaction by such West Indian political leaders as Norman Manley of Jamaica to Burnham's involvement in the 1953 Guianese constitutional crisis, the P.N.C.'s affliation to the Federal Labour party has had minimal significance.

Outside the Caribbean the P.N.C. had demonstrated a particularly strong affinity for Ghana supported by a generalized interest in the whole of newly independent Black Africa. The important financial aid and organizational assistance rendered the P.N.C. in the 1961 campaign by a private group of Negro professional persons in the United States does not imply a strong U.S. orientation in the P.N.C. The strongest pro-American feelings exist in the former U.D.P. membership under Carter's influence. An independent P.N.C. Government would probably form strong Commonwealth ties, adhere with more-or-less constancy to the 
neutralist nations that incline toward the Western bloc, and move in the orbit of whatever Eastern Caribbean grouping may succeed the present Federation of the West Indies.

Since 1957 an important point of cleavage between the P.P.P. and P.N.C. has been their avowed conceptions of democracy. The P.N.C. insists that it alone embodies the true democratic tradition of Western socialism with its strong emphasis on human rights to match its pledge of economic equality. Only a P.N.C. Government would thus be a safe custodian of individual rights in an independent Guiana. According to the P.N.C., Jagan's Government will substitute Soviet for British domination and inevitably conform to the totalitarian pattern of a "people's democracy."

Thus thrown on the defensive, P.P.P. leaders have taken considerable pains to validate their own claims as the bearers of an authentic democratic tradition. They cite with pride the record of their prolonged opposition to the British abridgment of civil rights after the 1953 crisis at a time when the Burnhamites were allegedly destroying the political unity of the working class. They stress the P.P.P. authorship of the "fundamental rights" section of the 1961 Constitution which introduced internal self-government. In addition to the conventional guarantee of freedom of religious worship, speech, and association, the P.P.P. stresses the provision for the protection accorded property-owners against Government's compulsory acquisition of their holdings except on payment of "prompt and adequate" compensation.

The P.P.P. further argues that it pays more than lip service to human and propertied rights. It was a P.P.P. Government that first "recognized and used" the Hindu and Moslem faiths in official ceremonies. Attention is drawn to the "fair" compensation the P.P.P. Government awarded the Demerara Electric Company when it assumed ownership, its sponsorship of a Land Registration Law which clarified the title rights of many small farmers, and its granting of nearly one hundred thousand acres of land to peasant farmers between 1957 and 1961 . The testimonials of confidence in a P.P.P. Government by the leading foreign enterprises, particularly that by Booker's Chairman Sir Jock Campbell, and their continued heavy investment in their Guianese holding are important inclusions in the P.P.P. defense.

Only the attainment of full independence will provide the ultimate test of the P.P.P.'s democratic pretensions. Positively it can be said that for four years a P.P.P. Government has operated within the accepted framework of British parliamentary practice and has been associated with a succession of fair and free elections. A favorable climate of opinion between the P.P.P. Government and foreign business firms indubitably exists at the present time. The historical memory of the aggressive and somewhat capricious P.P.P. Government in 1953 has been softened by the moderation and flexibility in approach to economic policy demonstrated by the Jagan Government since 1957. Much depends on the future success of the new Jagan Government's Development policy and the amount of technical and financial assistance which the Western bloc, particularly the United States, tenders in the immediate future. Any very sustained lag in economic ex- 
pansion may lead to an adoption of a much more doctrinaire Sovietized approach in Development policy with a consequent decline in democratic practices.

On the eve of independence the most grievous unresolved problem facing the political parties is the establishment of a true national unity. In the last year ethnic divisiveness has been dangerously exacerbated. It is a moot point whether either the P.P.P. or P.N.C., as they are presently constituted, can serve as an effective instrument to heal the breach between East Indian and African.

The roots of racial tension lie deep in the economic history of British Guiana. The East Indians first came to the colony in the post-emancipation period in the mid-nineteenth century to replace the freed African slaves on sugar plantations as indentured workers under short-term contracts. By 1917 there had arrived over a quarter-million East Indians, many of whom opted to remain permanently in British Guiana. They remained a culturally distinctive group, their continued adherence to Hindu and Muslim religious practices distinguishing them sharply from the predominantly Christian African population.

Gradually a marked occupational differentiation between the two groups became apparent. East Indians did field work on sugar plantations and tilled rice paddies. Africans predominated among sugar factory workers in the sub-managerial levels in bauxite mining. Other largely African occupations were the civil service, the police, the professions of law and teaching, which accounted for the African urban majorities.

In recent years, particularly since World War II, significantly large numbers of East Indians have transcended their previously inferior "coolie" status and have entered business and the professions. In this connection the growing stature of the Georgetown Junior Chamber of Commerce, composed mainly of a new generation of East Indian businessmen, is noteworthy, challenging the entrenched position of the predominantly European Senior Chamber of Commerce. Politically the Junior Chamber of Commerce is strongly pro-P.P.P. in orientation and is one of the forces operating to moderate the dogmatically Marxist tendency within the P.P.P.

Although neither the P.P.P. nor P.N.C. can afford to ignore the electoral realities which have been made the core support of each party ethnically distinctive, both proclaim their fidelity to the objective of national unity. P.P.P. spokesmen stress the class basis of their party's ideology. They draw attention to the historical role of the P.P.P. in diminishing the political influence of the East Indian Association and League of Coloured Peoples. They deny that the P.P.P. Government's agricultural policy deliberately favors the East Indian peasants at the expense of urban African workers, asserting that their commitment to well-rounded economic development in both agriculture and industry will ultimately benefit all Guianese regardless of race. They point proudly to their leadership of the Nationalist movement as the more vigorous champion of the rapid attainment of full independence in constitutional negotiations with the British. They place the onus for the present hightened racialist feeling on the disruptive action of the Burnhamite faction in dissolving the unity of the working-class move- 
ment in 1955. They emphasize the repeated P.P.P. efforts, always repelled by the P.N.C., to heal the ethnic breach by reunifying the popular movement.

In the P.N.C. an important fissure occurred in 1961 between the Burnhamite leadership and the stridently racialist faction led by Sydney King and H. $H$. Nicholson. King, one-time close associate of the Jagans and later a migrant to the P.N.C., had become by 1960 one of the most popular leaders of Burnham's party and editor of its influential weekly, the New Nation. Nicholson, a master at the colony's leading secondary school, Queen's College, had suddenly acquired local notoriety in 1961 under the pseudonym of "Vigilance" for a series of articles, published in the P.N.C. organ and reprinted in the conservative Daily Chronicle, attacking the East Indians and their political vehicle, the P.P.P. The King-Nicholson thesis was that the P.P.P. was not a genuine political party but merely a selfinterested association of East Indian capitalists and peasants who threatened to use their growing political power to victimize the African minority. King and Nicholson began to utilize this aggressively anti-Indian position as a rallying-point within the P.N.C. to replace Burnham as party leader, and an intensive intraparty power struggle, mostly concealed from public view, ensued.

At the outset of the 1961 campaign Burnham asserted that as P.N.C. leader he would be willing to "fly in the same plane" to London with Jagan to conduct negotiations for full independence. The outraged King issued his sensational proposal for the partition of British Guiana on racial lines. King's solution to Guianese racialism was a two-step proposal. First he suggested a "joint and equal prime ministership" shared by the leaders of the Indian and African peoples for a Guiana neutralized between East and West. An interracial "Watch Commission" was to be instituted to supervise the expenditure of Government funds and fair distribution of jobs. Anticipating Jagan's rejection of a joint prime ministership, King then proposed a partition of the country into separate African and Indian zones with an intermediate third zone "for those who wished to live with other races."

After the release of this political bombshell King and Nicholson were peremptorily expelled from the P.N.C. King became for a time an independent legislative candidate but later withdrew. Under King-Nicholson leadership the African Society for Racial Equality was formed to agitate for an ethnic partition and immediately won a mass response. The future relationship between the P.N.C. and its rebellious offshoot is uncertain. Doubtless King retains a wide following in the P.N.C., particularly in his home constituency of Buxton.

As the Government party the P.P.P. bears primary responsibility for some amelioration in this very marked racialist antagonism. Some initial steps were taken in this direction following the P.P.P.'s electoral victory in 1961 by the inclusion of several Negro leaders of the P.P.P. in the new home-rule cabinet and by Jagan's nomination of P.N.C. leader W. O. R. Kendall to be deputy Speaker of the New Legislative Assembly. Barring a fundamental political realignment along class rather than ethnic lines, which does not seem likely in the immediate future, a radical improvement in East Indian-African relations cannot be anticipated, so that the parties' asserted goal of national unity remans mainly a paper declaration. 
III

The 1961 General Election provided a concentrated summation of the main features of the party system. The campaign was conducted under the new constitution that represented the penultimate step toward full independence. ${ }^{4}$ The principal characteristics of the new governmental system were as follows: (1) a return to the bicameralism of the Waddington Constitution with a wholly elective legislative Assembly of thirty-five members chosen in single-member constituencies by plurality vote and a nominated Senate; (2) the creation of a policy-forming executive organ, the Council of Ministers headed by a premier, normally the leader of the majority party in the lower chamber, and solely responsible to that body; (3) a mixed composition in Senate membership, thirteen of whose members the governor would appoint on recommendation of the premier, three to represent minority opinion in the lower house and two in the sole discretion of the governor; (4) a limitation in the Senate's legislative authority to a suspensive veto of six months for ordinary legislation and of one month for a Money Bill, the latter necessarily originating in the Legislative Assembly; (5) the premier's domination of appointments to such key statutory boards as the Public Service and Police Service Commission; (6) the retention of Colonial Office control over defense and external affairs, excluding trade relations with foreign countries and the reiteration of the emergency powers of the British-appointed governor; and (7) an elaborate section of guaranteed "fundamental rights," as cited above.

Pitted against the two established parties were the conservative United Force and the less significant Guiana Independence Movement. The United Force epito mized the conservative third-party contestants with no mass base that have waged a losing political struggle since 1953. Its dominant figure was its founder and leader, Peter D'Aguiar, a wealthy brewer of Portuguese descent and a nominal Roman Catholic. The ideological trademark of the United Force was a firm espousal of the free-enterprise system as the principal catalyst of the country's rapid economic development coupled with a shrill anticommunism. This placed the U.F. well to the right in the Guianese political spectrum, sharply distinguishing it from both the P.P.P. and P.N.C.

The strongest single motivation for organizing the U.F. in late 1960 was to form an electoral combination strong enough to defeat the feared incumbent P.P.P. Its actual organization had been preceded by long months of negotiations between D'Aguiar and the P.N.C. to provide a single major opposing party to the P.P.P. These broke down over the composition of the executive of the proposed party merger. In view of the markedly different policy outlook of D'Aguiar and the Burnhamites such a union would have had dubious viability. Fear and dislike of the P.P.P. would have been virtually its only integrative element.

By election time in 1961 the U.F. had become a carefully organized, wellfinanced political grouping. Its leadership and clientele were more ethnically heterogeneous than either of its major opponents and included Portuguese and Chinese businessmen, wealthy East Indian landlords and light-colored Negro professional persons. It placed candidates in all thirty-five constituencies. Its

${ }^{4}$ British Guiana Constitutional Instruments, Georgetown, B.G., 1961. 
weekly periodical, the Sun, and its veritable cascade of campaign literature were more professionally edited than its partisan counterparts.

D'Aguiar proved an articulate, indefatigable campaigner, obviously working against heavy odds. In the secondary tier of U.F. leadership, only Ann Jardim, a young English-educated Guianese, demonstrated first-rate oratorical and campaigning skill. In the postelection period she was appointed to one of the three minority seats in the Senate.

In the campaign the U.F. stressed that it alone was qualified to bring about the rapid modernization and expansion of the Guianese economy. D'Aguiar with his record of outstanding competence in business management was deemed supremely capable of galvanizing the whole Development effort and inspiring sufficient confidence abroad to elicit vastly expanded amounts of foreign investment, both private and governmental. D'Aguiar, it was asserted, would preserve the proper balance between the public and private sectors of the economy with Government providing the necessary roads, land clearance, water supply and social services to encourage the opening up of the interior. A U.F. Government would also sponsor a U.S.-modeled Homestead Act under which settlers would receive free grants of land under freehold tenure. These multiple efforts would effectively remove the specter of unemployment. This prospectus was given the fulsome campaign label of "economic dynamism" and presented as a stark contrast to the insistence of the U.F. opponents on a planned economy in which the public and private sectors would be inevitably amalgamated with an attendant loss of individual liberties.

A strategem of fear dominated the U.F. campaign effort. P.N.C. "socialism" was allegedly indistinguishable from P.P.P. "communism" and the electoral victory of either would ring the death-knell of freedom and democracy in British Guiana. A typical warning by D'Aguiar was the following statement:

. . a ask yourself what that future can be if the methods used by the Russian Communists are put into operation here - and please don't say "it cannot happen" - unfortunately it can.

When, if the P.P.P. and P.N.C. have their way you will not be able to argue freely about your Government and what they do and do not do, when all you will have to do is agree and keep silent, or talk and go to the concentration camp and your rights as a citizen taken away ... Put the P.P.P. or the P.N.C. in power and you will have made the rod of slavery for your own back. ${ }^{s}$

In contrast to the neutralist professions of the P.P.P. and P.N.C. the United Force was unequivocally pro-Western in its external outlook. This attitude was buttressed by the U.F. conviction that only the leading capitalist nations of the "Free World" bloc, namely the United States and Britain, were a reliable source for the large amounts of capital investment that a "dynamized" Guianese economy would require. Only under a U.F. Government would meaningful Commonwealth ties be cemented, it was argued.

Finally the U.F. presented itself as the answer to the grievous problem of racialism which threatened the country's peaceful development. It pledged itself to the active promotion of an integrated society to form "one United Guianese Nation" and pointed to its own mixed membership as a suggestive harbinger.

\footnotetext{
${ }^{5}$ Transcript of U.F. elections broadcast, Daily Chronicle, August 18, 1961.
} 
The opponents of the U.F. derided this claim, asserting that the U.F. represented in new guise the old colonial society and was dominated by entrenched highstatus groups.

The Guiana Independence Movement was chiefly significant as the personal vehicle of Jai Narine Singh, whose flamboyant political style has titillated Guianese politics for a decade as he moved from the P.P.P. to the P.N.C. to political independence. His G.I.M. was militantly nationalist, favoring independence outside the Commonwealth and a reorientation away from the British West Indies to the embracing of a vague program of "continental destiny." With its predominantly East Indian clientele the election-eve withdrawal of the three G.I.M. legislative candidates benefitted the P.P.P.

In Nomination Day slate-making each of the three principal contesting parties presented a multiracial image to the electorate. In this endeavor the U.F. and P.P.P. were considerably more successful than the P.N.C. The U.F., which throughout the campaign stressed its objective of "racial integration," offered as candidates fourteen East Indians, twelve Africans, three Chinese, three Portuguese, two Amerindians, and one English. The P.P.P. lineup of twenty-nine candidates included fourteen East Indians, twelve Africans and three Portuguese. Significantly eight Africans were given "safe" P.P.P. constituencies. Twenty-four of the P.N.C. candidates were Africans, six were East Indians, three Portuguese, one Chinese, and one of Amerindian mixture.

The party candidates ran under a unifying pariy symbol, important when the degree of the electorate's literacy remained uncertain. The P.P.P. cup had been its 1953 symbol. The P.N.C. broom was linked with its campaign slogan "sweep them out and keep them out." The slogan covered both the P.P.P. incumbents and the "old guard" represented by the U.F. The U.F. sun implied a happy future for the country if its proposals for economic development were adopted. Of the three symbols the P.N.C. broom was the most aggressively employed during the campaign. At opposition party street-rallies several P.N.C. supporters on bicycles frequently appeared brandishing brooms and heckling the speaker by shouting the P.N.C. slogan.

Unlike their Jamaican counterparts the Guianese parties do not have tradeunion affiliates. The Trades Union Council, loosely formed of some twenty unions, maintains formal political neutrality and does not endorse political candidates. In the 1961 campaign a serious cleavage in political sympathies was evident between the T.U.C. leadership and its rank-and-file membership. The former favored the U.F., the support of the latter being divided between the P.P.P. and the P.N.C.

This division was especially marked in the powerful Man-Power Citizens' Association, holding a near-monopoly position in the sugar industry. Richard Ishmael, president of both the M.P.C.A. and T.U.C., was one of the five independent legislative candidates and professed to be organized labor's only "true" representative in the campaign. He was bitterly anti-Jagan, while the bulk of the M.P.C.A. membership, largely East Indian, was strongly P.P.P. Shortly before Election Day, Ishmael withdrew his candidacy. The P.P.P. victory foreshadowed an imminent shift in this trade-union leadership. 
The P.N.C.-oriented affiliates in the T.U.C. were unions in which African workers predominated, as in the organizations of transport, Government and postoffice workers. An outstanding trade-union leader, Andrew Jackson, head of the influential Government employees' union, served simultaneously as General Secretary of the P.N.C. Jackson was narrowly defeated for a Georgetown legislative seat by his U.F. opponent.

The political proclivities of certain Christian religious groups were activated during the campaign by the intrusion of the issue of dual educational control. In the spring of 1961 the P.P.P. Government had sponsored legislation which authorized the Government to assume control of fifty-one denominational schools. Since 1953 the P.P.P. has opposed the established system of Government financial subsidies for schools dominated by religious sects as outmoded in modern secular society. The influential hierarchies of the Roman Catholic and Anglican churches became particularly alarmed by the 1961 Education Law, which in their view constituted "the thin edge of the Communist wedge." Two pressure groups, the Citizens' Committee and the Defenders of Freedom, were formed to protest the law, organize street demonstrations against it, and petition the Colonial Office to disallow it. U.F. supporters were prominent in these organizations.

The two principal campaign methods employed by the parties were houseto-house canvassing and street-corner political rallies. The former was comprehensively conducted by the parties' Group Members in the different constituencies and was designed to familiarize the voters with their parties' policy positions and local candidates. In such contacts the weekly organs of the parties, the P.P.P. Thunder, the P.N.C. Nation, and the U.F. Sun, provided appropriately partisan accounts of recent campaign developments and useful ammunition against opposition parties.

Customarily the rallies were held in the evening hours stretching between eight and eleven o'clock. Teams of a half-dozen party orators were utilized to castigate the opposition and extol the speakers' own party, and these fiery messages were relayed by loud-speaker systems into the surrounding neighborhoods. In conformity with a universally followed practice the final speech of the evening was reserved for the highest-ranking party leader present.

While the local party faithful usually comprised the audience at these rallies, there occurred a number of incidents of refuse- and stone-throwing presumably by party opponents. Unlike its two opponents, the P.P.P. did not put up candidates in six of the thirty-five constituencies, mostly those with heavy African majorities, and hence tended to concentrate its rallies in its rural East Indian strongholds and a few crucial marginal constituencies. The P.N.C. neglected the rural constituencies until the last days of the campaign.

An important supplement to these campaigning methods was a series of election broadcasts by the four parties contesting the election and heard on the country's two broadcasting outlets. In these the party leaders made their most impressive reasoned appeals to the electorate. Typically a single broadcast was confined to one aspect of the party platform such as agricultural or educational policy. In a country with uncertain literacy and where newspaper circulation is confined mostly to urban areas these radio broadcasts were of prime importance. 
The marked increase in the professionalized character of the 1961 campaign appeals can be chiefly attributed to external assistance available to each of the three major contestants. A group of American Negroes of Guianese origins, organized as a "Help Guiana" Committee, came from the United States to aid the P.N.C. The Trinidadian leftist Jack Kelshall provided major assistance to the P.P.P. and after election was appointed as Jagan's private secretary. The U.F. received some Conservative party advice from Britain. In general, the U.F. appeals were the most polished and were presented with the most dramatic flair.

In the daily press the United Force had a virtual official organ in the strongly partisan Daily Chronicle of which D'Aguiar is principal owner. The other two dailies, the Guiana Graphic and the Evening Post, successfully separated their campaign coverage from their editorial commentary, and neither was noticeably partisan.

As the leading issues racialism, the future prospect of a communistic Guiana under a P.P.P. Government, and the future shape of economic development dominated the campaign, the parties taking the stands outlined above. The U.F. took the initiative in alerting the electorate to the communist threat represented by the P.P.P. to the point of overstatement, and gave the impression that its avowal of ethnic integration was more genuine than the habitual multiracial window-dressing to which the P.N.C. and P.P.P. were prone. Also in Development policy the U.F. used the boldest strokes in sketching out its grandoise vision of an energized Guianese economy fed by an anticipated gusher of foreign capital. The P.P.P. held the advantage of comprising the incumbent Government with a combination of militant ideology and a moderate, responsible administrative record. Standing between what it defined as the "communist" and "fascist" extremes of the P.P.P. and U.F., the P.N.C. held a middle position that proved difficult to dramatize effectively.

Election Day came after three weeks of intensive campaigning. The undercurrent of violence that marked the final days was never precipitated in a grave incident. All five independent candidates had earlier withdrawn. The voter turnout proved impressively large with a national average of 89.4 per cent of an eligible electorate of 246,125 persons. In nineteen of the thirty-five constituencies the turnout was 90 per cent and over.

In a close popular vote the P.P.P. decisively won twenty seats in the Legislative Assembly which precluded the necessity of a coalition cabinet. The P.P.P. percentage of the popular vote was 42.63 , compared with the 40.99 per cent won by the P.N.C. and the U.F.'s 16.38 per cent. With its vote heavily concentrated in the urban and bauxite industrial areas the P.N.C. won only eleven Assembly seats. The U.F. gained four seats, winning two very close contests from the P.N.C. in Georgetown constituencies.

Racialism remained the primary determinant of voting behavior. The East Indian rice farmers and estate workers in the coastal rural constituencies again voted strongly in favor of P.P.P. and largely determined the election outcome. The African town vote remained the indispensable core of the P.N.C. electorate. Some diminution in this over-all pattern was evident in three crucially important 
marginal constituencies where large numbers of Africans voted P.P.P. and in one constituency with an East Indian majority won by the P.N.C.

The impact of racialism on voting behavior was closely linked to the personalist element which still strongly marks Guianese politics. For the East Indian Jagan and the Negro Burnham are the very embodiment of their separate political groupings, and much of their campaign rivalry was focused in the question of whether an East Indian or African should hold the honor of being British Guiana's first premier.

At the same time Guianese politics demonstrated a fairly high degree of issue-orientation. This was reflected in the great care all the parties devoted to the preparation of their detailed election manifestoes, to outlining their policy positions, and to the election broadcasts, as well as the marked ideological emphases in their weekly press, particularly in the P.P.P. Thunder.

The U.F. made an indifferent showing and faced an uncertain political future. Twenty-three of its candidates lost their electoral deposits. Its principal areas of strength were the mining and timber districts of the interior, sparsely inhabited chiefly by the Catholic Amerindian population. Its two Georgetown victories were widely attributed to Jagan's order that P.P.P. supporters in those constituencies without P.P.P. candidates were to vote against the P.N.C. by voting U.F. Here in Central Georgetown the U.F. enjoyed its most dramatic victory when D'Aguiar bested Winifred Gaskin, P.N.C. chairman, by slightly over eight hundred votes.

From this analysis it cannot be deduced that British Guiana has as yet attained a stable party system. In the next decade a realignment of present political forces is probable. The future chances of the P.N.C. in advancing from its present minority position are not bright. Its present espousal of proportional representation to replace the existing "first past the post" system is not likely to lead to the adoption of this reform in the new constitutional system under independence. More significantly the numerically dominant East Indian population will be increasing at a proportionately faster rate than the Negroes in the immediate future. This is especially ominous for the P.N.C. as the most ethnically homogeneous political party.

Despite the past failure of merger negotiations between the P.N.C. and U.F., a pooling of the strength of these two organizations remains an active political possibility. But the future population projections, so favorable to the P.P.P., do not augur well for the electoral success of such a merger. It is difficult to envision how a single political organization could, in the long run, contain within itself two such commanding political figures as Burnham and D'Aguiar, especially when they have spelled out their ideological differences so caustically.

The capacity of the P.P.P. to attract sizable numbers of African voters, noted in the 1961 election, suggests that the P.P.P. may in the future become the major political voice of the masses as in 1953. The ultimate realization of this possibility rests on several variables: (1) how successfully Jagan can placate and win over to the P.P.P. important segments of the African population; (2) the possible future attraction of the P.P.P. if it embodies a strikingly successful Development 
policy; and (3) whether or not Burnham can decisively improve his party's competitive position.

If the P.P.P. were enabled to assert its original role as leader of the popular forces a political realignment along class lines might replace the present racial emphasis. Thus the formation of a solidly based conservative party would be stimulated. This prospect will in turn depend on the emergence of an enlarged middle class, whose outlook is less bound to the dying Colonial regime than was the U.F.

Two extremist possibilities remain. One is further deterioration in the present precarious degree of national unity leading to apartheid. The King-Nicholson clique would become the principal beneficiaries of such a trend. The accelerated activities of their African Society for Racial Equality keep this a live prospect. The second is that Jagan, if he meets continuous frustration in implementing his Development program, may introduce a Sovietized "people's democracy," abandoning his present commitment to parliamentary democracy. In neither eventuality would the present party system or any presently anticipated modification survive. 